\title{
ジョブのジグ・機械割り当てを考慮した スケジューラの開発*
}

\author{
渡辺美知子“古川正志” 三添朗宏 ${ }^{* *}$ 渡辺龍男 ${ }^{* *}$ 嘉数侑昇 ${ }^{*}$
}

Development of a Practical Scheduler Taking into Account of Assignment of Jigs and Machines Assignment to Jobs

Michiko WATANABE, Masashi FURUKAWA, Akihiro MIZOE, Tatsuo WATANABE and Yukinori KAKAZU

\begin{abstract}
For the eff icient ope ration at a manuf acturing factory requir ed to produce a $s$ mall size a nd various ty pe of products, it is important to make a good schedule taking in to account of jigs and machines assignment to jobs. This is because a tool and jigs are common ly equ ipped with machine $s$. In this study, a pra ctical scheduler is deve loped, which solves job-shop schedu ling proble $\mathrm{m}$ including the jobs a nd jigs assig nment to the machine $s$ by u se of a genet ic algorithm (GA). A new chromosome representa tion is introduced into GA for applying it to the given problem and effec tive genetic operations are exami ned. Furthermore, a user-friendly graphic interface is reported that produces a suitable database for the operation. Numerical experiments verify that the proposed GA solves the job-shop scheduling in a practical time.
\end{abstract}

Key words: job-shop scheduling, quadratic assignment problem, genetic algorithm, evolutionary computation

\section{1. 腥言}

近年, FMS 工場をもつ大企業のみならず中小企業においでも需 要の多粎化や個性化に対して多種少量生産加変種変量生産人 の移行が進み、こ机らを寒現寸る迅速か力効率的な生産体制が強 く望まれている，従って，このような生産体制を作るには中小企 業においても実用的でかつ安価なジョブショッブスケジューラ の開発が強く望まれている。

しかしながら，多くの中小の金型工場や成形工場では実用的で かつ安価なジョブショッブスケジューラがほとんど導入されて おらず，熟練者による経験に基ついたスケジュール作りが行われ ているのが現状である。また，スケジュール作成は人間が行い， それをデータべースとして計算機で日程管理を表示している場 合多多い.

こうした中小企業の生産過程では，ある整造工程に対していく つかの機械が割り当てられる侯補として存在し，かつ機械に对し てもその機倳専用及びいくつかの機械に対して共通のジグをも ち，また同じように尃用及び共通の工具を持つことが多い。これ は機械やジグ，工具などの製造におけ后資源が少なく，限ら机て いるためである，それゆえに，機峨やジク，工具などの資源の租 合せを考慮した上でスケジューリングの作成を行う必要がある。 同粎のスケジニーリンダ問題は FMS 工場においても生している。 すなわち，マシニングセンタやマシニングセルに対して，いつも 同じマガジンや工具を取り付けておくのではなく，マガジンや工 具を分離して管理し，必要に応じてそれらを組合せる工具配分と 負荷計画問題である゙'。

このようなスケジューリング問題は，単にジョブショッブ問題

* 原稿受付 平成 11 年 3 月 15 日

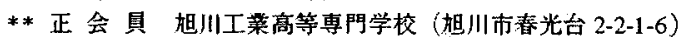

***（株）シ久テムラボムラタ（大津市石山寺 3-24-1）

+ 正会貝 北海道大学大学院工学研究科（札棍市北区北 13 条西 8 丁目)
であるだけでなく，同時にジグ・工具の機械割り当て問題をも解 〈必要がある。しかしながら，藤井らりによって指摘されるよう にこうした問題を数理計画法やとューリスティックな問題とし て取り扱うときは，工具・ジグをグルーブ化したり機械群をセル 化し，簡易化した問題として取り扱う場合が多い，一方，遺伝ア ルゴリスム（Genetic Algorithm, GA）は最適化の一般手法として 多方面で使用されスケジューリング問題に対してもテイスパッ チ規則やランタム法と比較して良い䊅果が得られることが報告 されている2゙ー3．本研究では上記に示した問題に対して，GA を実用レベルで適用し，また，既存のデータベースを容易に作成 する簡便なエーザ・インターフェースの寒現を目的とする。

GA 採用したスケジューリング問題へのアプローチは， Syswerda ${ }^{2)}$ 中 Whitley ら 3)によって 1980 年代後半の研究がまと められており，また，日本にまいても小林ら4)，玉置ら5)，大 会ら 6) 及び飯間ら")が，遺伝子の設計方針や遺伝演算として探 用される演算の効率などに関する精力的な研究を行っている。こ れらの研究から GA 実用的に利用するには; (1)染色体の効果的 な構文表現 (Genotype Representation),(2)染色体の解釈(Phenotype Representation），(3)使用する遺伝演算の選択，の三つを考慮する ことが重要である。これらは別個に存在するのではなく相互に影 䈉する.小林らの研究は構文表現において形質遺伝を良好に設計 することで遺伝演算が効果的に働くことを報告しており，大會ら は染色体の構文表現から染色体の解釈に翻訳される過程で中間 遗伝子を多く作り出すことが有効であることを報告している．

しかしながら，現在普及している PC（クロックタイム $400 \mathrm{MHz}$ ）の能力でこれらの方法を採用することは，長大な計算 時間から奉用的ではないといえる，本研究では，先の問題に道伝 アルゴリズムを適用するために，染色体構文表現をジョブ・ショ ップ部とジグ・機械の工具割り当て部の合成から構成した．すな わち，前者にはSyswerda ${ }^{2)}$ の実験において比較的良い耛果を示 した順序表現を変更し，染色体の解釈において工程先行関保を赛 現できる形式に変形した表現を提案する：後者には染色体の解釈 においてモード計算によって工具・機械の割り当でがジョブショ 
ップ部の変更に対応できる2 進数染色体構文表現を提案する。ま た，遺伝演算として単純 $\mathrm{GA}$ の淘汰・交叉・笑然变異に加え逆位

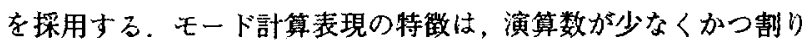
当て問題については実行可能な割り当てを奏現することにある。 数值計算実験においては，山村の方法と比較しショゴョップ部 の有効性を確㒛するとともに，採用した演算子の効果を報告する。 また，最後に事用化のために作成した商便なユーザインターフェ 一スの概要を報告する。

\section{2. ジグ・譏械の工具割り当てを考虑したジョフ} ショッブスケジューリング問題

ここでは，本研究で取り扱うジグ・機械の工具割り当てを考慮 したジョブショッフスケジューリング問題について述ベる。

\section{1 記号の定義}

以降で取り扱う記号を以下のように定義する。

$J$ ：与えられたジョプの集合

$n: \quad シ ゙ ョ フ ゙$ 数

$J_{I}: \quad シ ゙ ョ フ 十$ 集合に含まれるジョブi

$M$ : 機械集合

$m:$ 機械数

$M_{j}$ ：機械集含に含まれる機械 $j$

$J_{i j}$ : 機械 $j$ で加工されるジョブiの工程

$n_{j}$ : 機械 $j$ に割り当てられた工程数

$N$ ：工程 $J_{i j}$ の総数

$t_{i j}:$ 工程 $J_{i j}$ の加工時間

$B$ ：与无られたジグの集合

$B\left(J_{i j}\right)$ ：工程に使用可能なジダの集合

$B_{k}\left(J_{i j}\right): \quad B\left(J_{i j}\right)$ に含まれるジグk

$b\left(J_{i j}\right): \quad B\left(J_{i j}\right)$ に含まれるジグの総数

$M\left(B_{k}\left(J_{i j}\right)\right) \quad シ ゙ ク ゙ B_{k}\left(J_{i j}\right)$ 取付け可能な機械の集合

$M_{j}\left(B_{k}\left(J_{i j}\right)\right): M\left(B_{k}\left(J_{i j}\right)\right)$ に含ま机る機械 $j$

$m\left(B_{k}\left(J_{l j}\right)\right): M_{j}\left(B_{k}\left(J_{i j}\right)\right)$ 総数

$\left(\ll J_{i j}\right)$ ：工程 $J_{i j}$ の先行関保 (仕事順序)

$W_{j h}$ : 樴械 $j$ の $h$ 番目の工程の待亏時間

$D ： シ ゙ ョ フ i の$ 納期時刻の集合

$D_{I}$ : ジョフ $i$ の納期時刻

$s_{j}(h)$ : 機械 $j$ におけるh番目までの工程順序

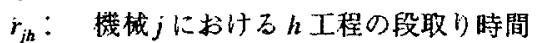

\section{2 問題の記述}

ジョブ集合 $J$ と納期時刻の集合 $D$ が注文として与えられる. ショョブ $J_{i}$ の工程 $J_{i j}$ には1本の工具肪割门当てられ，この工具に よって使用可能な複数のジダと機械があらかじめ与えられてい る上する。すなわち，ショプの工程 $J_{i j}$ に対して使用可能な複数 のジグと機械が存在する．また，ジョブ $J_{i}$ の工程 $J_{i j}$ には先行関 保 (仕事順序) (《J J ジョブJにジダと機栈の割り当てを決定し，かつ設定した評価基 準を最小にするような工程計画（日程計画）を工程の先行関係 $\left(\ll<J_{i j}\right)$ を満たすように決定する。

制約条件として上記の先行関係の他に，工程の取り掛かり時間 を 8 時から 17 時までと設定する。これは工場の作業者の労働時 間内に工程の段取りを終了させるためである。

本問題は; ジョブの工程 $J_{i j}$ に対するジグと機樴の割り当て方 により加工能率が変化するため，一般のジョブショップ問題にみ られる工程の順序決定問題と, 工程に対するジグと機械の 2 次割
り当て問題を含んでいる.

\section{3 加工時間の㖕算}

ジョブの工程 $J_{i j}$ に对するジク $B_{k}\left(J_{i j}\right)$ と機械 $M_{j}\left(B_{k}\left(J_{i j}\right)\right)$ の割り 当てがジク $k$ 及び機峨 $j$ と决定したとき，この工程が $(h+1)$ 番目 に機械 $j$ で処理されるとすれば，以下のように加工時間 $t_{i j}$ を決定 ナる.

$$
t_{i j}=r_{j h}+\left(\bmod \left[R_{i}, e_{j k}\right]+1\right) e_{j k}
$$

ここで, $\bmod [x, y]$ は $x$ の $y$ によるモード計算を示し， $R_{i}$ は一つの ショョブが要求する製品の品数, $e_{j k}$ はジョフに割り当てられた工 具とジダによる 1 半製品当たりの加工時間である，従って，異な る工程が連繶して同じジグ，及び機械を使用する場合には，段取 り時間が不要となるので加工時間は短縮する。

\section{4 スケジューリング評価}

以下の 4 つの評洒を採用する。

(1) 最大滞留時間の最小化

機械 $j$ の $(h+1)$ 番目の漁留時間 $C(s(h+1))$ は,

$$
C\left(s_{j}(h+1)\right)=C\left(s_{j}(h)\right)+W_{j, h+1}+t_{i j}
$$

によって計算する、これから，最大滞留時間の最小化は，

$$
\min _{s_{j}\left(n_{j}\right)} F_{l}=\max _{j}\left[C_{j}\left(s_{j}\left(n_{j}\right)\right)\right]
$$

なる機械 $j$ の工程（加工）順序 $s_{j}\left(n_{j}\right)$ を求めることである. $n_{j}$ はジ ヨブの工程に対するジグと機械の割り当てが決定したときに定 まる。

(2) 待ち時間総和の最小化

すべてのジョプ工程の待ち時間の紷和を最小化する。これは，

$$
\min _{s_{j}\left(n_{j}\right)} \quad F_{2}=\sum_{j=1}^{m} \sum_{h=1}^{n_{j}} W_{j h}
$$

なる機械 $j$ の工程順序 $s_{j}\left(n_{j}\right)$ を求めることである.

(3) 納期遅机時間総和の最小化

ジョブJの終了時間を $C_{i}$ とする。このとき納期迤れ時間紹和の 最小化は，

$$
\min _{s_{j}\left(n_{j}\right)} \quad F_{3}=\sum_{j=1}^{n}\left[\max \left(C_{i}-D_{i}, 0\right)\right]
$$

なる機械 $j$ の程順序 $s_{j}\left(n_{j}\right)$ を求めることとなる.

(4) 段取り総和時間の最小化

段取り時間総和の最小化は，

$$
\min _{s_{j}\left(n_{j}\right)} \quad F_{4}=\sum_{j=1}^{m} \sum_{h=1}^{n_{j}} r_{j h}
$$

であるが，本研究では単に段取りの回数を $F_{4}$ として操用する。

\section{3. 道伝アルゴリズムの設計}

本問題に遺伝アルゴリスムを適用するためには，

(1) ジョフ工程 $J_{i j}$ の順序決定問題

(2) ジョフエ程 $J_{i j}$ へのジグの割り当て問題

(3) ジョフ工程 $J_{i j}$ への機械の割り当て問題

が同時に解けるような染色体遺伝子を設計し，かつ効果的な遺伝

演算を導入する必要がある。

\section{1 遗伝子の全体設計}

染色体遺伝子は(1)（3)の解を同時に表現できるように $3 N$ バイ トを1ストリングとして用意する。ここで， $N$ はジョブ集合 $J の$ 含む棇工程数とする．ジョフ $J_{i}$ に含まれる工程数を $N_{j}$ とすれば， 


$$
N=\sum_{j} N_{j}
$$

となる．遺伝子は最初のNバイトをジョブ部と呼び工程項序を割 り当てる。続く $N$ バイトをジグ部と呼び各工程で使用するジグ, 最後のNバイト萎機傤部と呼び各工程で使用する機械を割り当て 己.

\section{2 ジョフ部の通伝子表現とその翻訳}

ジョブ部の表現にはTSP問題で開発された順序表現す)を多重遺 伝子として採用する。順序表現は単一樴械の場合以下の上うに作 成される。

(1) リストにジョブ番号順に並べ，1 加ら順にリストにアドレ スを与える。

（2）ランダムトアドレス唓囲の整数を発生し，そのアドレスを遭 伝于の先頭加順に2 進化して格种する。

(3)リストからアドレスのジョブを除去し，再度リストに 1 から 順にアドレスを付け直す。

(4)リストが架になったら終了寸る。そうでないときは(2)へ戻る。 遗伝子の翻訳（形質表現）は，卡の先頭からアドレスを 10 進 化し，そのアドレスに対応するリストのジョブ番号在取り出し， その後リストのその部分を除去し，この手続きを緑り返してジョ ブ順序を得る

本問題は単一機械ではないことと，各ジョブの工程には先行関 保が存在するため，上記表現を直接採用できない，従って，順序 表現の手続き(1)を以下のように变更する。

(1) リストの最初から $N_{1}$ 個にジョフ番号 1，次の $N_{2}$ 個に番号 2,

$\cdots$, 最後の $N_{n}$ 個にジョブ番号 $n$ 孛格納し， 1 加ら順にリスト にアドレスを与充る。

これは同じジョプ番号が連続して初期のリストに格种される から，遺伝子は同じショフをその工程数だけ含んだ表現となる。 従って，この遺伝子表現を多重遺伝子とここでは名付ける。

遺伝于の翻訳は先々同じであるが，同じジョブ番号が現れるご とに，工程の先行関保順にジグと機械をジグ部と機械部から決定 し，アクティブスケジュールを作成する，アクティブスケジュー ルの決定を行う時に，工程の開始時間が8〜17 時以外であれば， その開始時間は翌日の 8 時とする。

\section{3 ジグ部の䢔伝子表現とその翻訳}

ジグ部のいバイト番目をジョブ部のいバイト番目に対応させ， 0 255の2 進数をランダムに格納する。この10進数を $g(u)$ と置 く、 $u$ バイト番目のジョフ部は工程 $J_{i j}$ を定めるから，これによ って使用可能なジグ集合 $\mathrm{B}\left(\mathrm{J}_{\mathrm{ij}}\right)$ とジグ数 $b\left(J_{i j}\right)$ が決定される。 の上き：ジグkは以下の計算によって求める。

$$
B_{k}\left(J_{i j}\right)=\arg \left(\bmod \left[g(u), b\left(J_{i j}\right)\right]+1\right)
$$

ここで，arg は引数 $k$ 定める関数とする。しジョブ部が突然 変異や交叉によって变化してb，そ礼に対応した工程 $J_{i j}$ が現れ， その工程により使用可能なジグ集合 $B\left(J_{i j}\right)$ とジグ数 $b\left(J_{i j}\right)$ が指定 される。徉って，遺伝子に格納されている值は影響を受けず，こ れを変更する必要がない。これは，ショプ工程を環境とすると， 同一遺伝子が璄境が变化すると別の形質発現する一つの表現 方式である。また，同一時間带に他の機械に選択されたジグが使 用されている場合は，ジョブ部のアクティブスケジュールの決定 の時に，工程の開始時間を重複しないように工程の開始時間应 ビジグを採用している工程の終了時間とする。

\section{4 機榑部の遺伝子表現とその翻訳}

ジグ部と同様に決定する。すなわち，機械部のいバイト番目を ジグ部のルバイト番目に对応させ，0〜255の2 進数安ランダムに
格納し、この 10 進数を $p(u)$ と置く。 $u$ バイト番目のジグ $k$ は使 用可能な機械集合 $M\left(B_{k}\left(J_{i j}\right)\right)$ と機械数 $m\left(B_{k}\left(J_{i j}\right)\right)$ を決定し, 機械 $j$ は以下の計算によって求める。

$$
M_{j}\left(B_{k}\left(J_{i j}\right)\right)=\arg \left(\bmod \left[p(u), m\left(B_{k}\left(J_{i j}\right)\right)\right]+1\right)
$$

機械部も遺伝子は直接ジョブ部とジグ部の遭伝演算による影暗 をジグ部同様に受けない.工程と機械の決定によりアクティフスス タジュールが決定される。

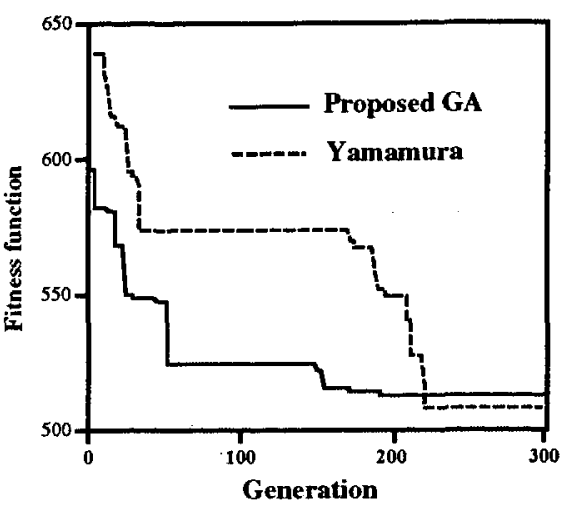

Fig. 1 A comparison of convergence curves

\section{5 造伝演算}

遺伝演算はジョブ部，ジグ部，機械部それぞれ別個に適用する。 ジョブ部には順序表現による 1 点及び 2 点交叉, 1 点突然変異, 逆位を設定した比率で実施する。なお，これらは 1 バイトを単位 として行う。ジグ部及び機械部は，単純遺伝アルゴリズムの 1 点 交叉及びバイナリ一反転による突然变異を実施する。個体群でエ リート保存を 1 個体適用し，淘汰は個体数を 50２00位と仮定し， Fortune rouletteによらず，上位指定率の個体数を下位に同数複製 する淘汰圧方式を採用する。

\section{6 適応関数}

2.4 章で述べた 4 つの評価関数にウェイトを乗じたスカラー 関数として使用寸る。これは，

$$
F=w_{1} F_{1}+w_{2} F_{2}+w_{3} F_{3}+w_{4} F_{4}
$$

と定式化される。ウェイト值 $w_{t}^{*} \sim w_{4}$ は工場の状況によって任意 に設定可能とする。

\section{4. 数值計算実糇}

これまでに述べた遺伝アルゴリズムを適用してその性能を調 べる数值計算実験を行った．実験の内容は，(1)多重遗伝子の有効 性を調ベる，(2)遺伝子演算の効果を確認する，(3)デスパッチン ダルールと本方法を比較する，である，

\section{1 多重遺伝子の有効性に関する実䟻}

多重遺伝子がどのくらいの有効性を持つかを調べるため，小林 らのアルゴリズムとの比較をジョブ部に関してのみ行った，遺伝 演算は 1 点交叉, 突然変異, 淘汰のみを採用し, 通常のショブシ ヨップスケジューリング問題を取り扱った。すなわち，nジョフ $m$ 機珹が与えられ，これらのジョブ工程には先行関保が指定され る問題である．実験条件としては，突然变異率 0.03 , 交叉率 0.06 , 淘汰圧 0.7 , ジョブ数 20 , 機械数 20 とし, 各工程の加工時間は 20〜40の間の一㥞乱数で発生し, 工程順序も一様乱数で定めた。 また，個体数を 200 とした。

このときの最大漁留時間を評価とした収束曲線を図 1 に示す。 これから多重遺伝子による方法は収束が早いが，エンドダームで 


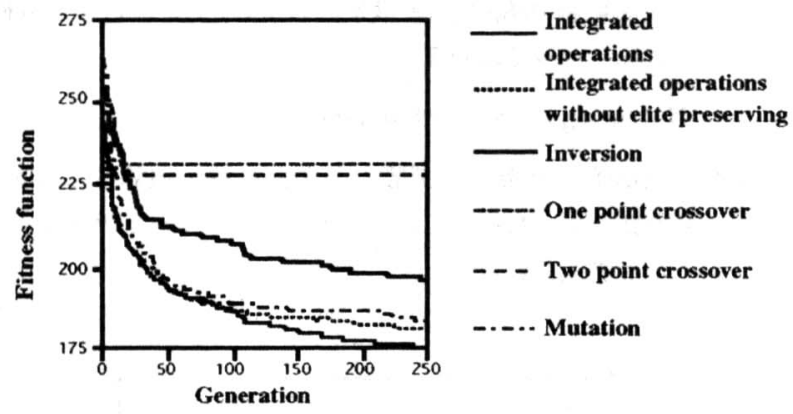

Fig. 2 Effectiveness of genetic operations

Table 1. Comparison with dispatching rules

\begin{tabular}{c|c|c|c|c|c}
\hline & $\begin{array}{c}F_{1} \\
\text { day }\end{array}$ & $\begin{array}{c}F_{2} \\
\text { day }\end{array}$ & $\begin{array}{c}F_{3} \\
\mathrm{~h}\end{array}$ & $\begin{array}{c}F_{4} \\
\text { day }\end{array}$ & $\begin{array}{c}\text { Time } \\
\mathrm{sec}\end{array}$ \\
\hline SPT & 401.07 & 354.90 & 42.00 & 48.00 & 0.015 \\
\hline LPT & 297.03 & 260.32 & 69.00 & 45.00 & 0.016 \\
\hline DDATE & 255.09 & 222.19 & 0.00 & 40.00 & 0.016 \\
\hline GA & 168.06 & 143.86 & 0.00 & 32.00 & 6.75 \\
\hline
\end{tabular}

は山村らのアルゴリズムが勝ることがわかった. 一方, Indy 5000 による計算時間の比較を行うと，300 世代の計算で多重遺伝子に よる方法は約 5 秒, 山村らの方法は約 60 秒を要し, 多重遺伝子 による計算は演算数が少ないことがわかった.この傾向は平均滞 留時間による評価でも同様であった。

\section{2 遺伝演算の効果}

各遺伝演算がどれだけ効果を持つかを調べるためにジョブ部 には淘汰と各遺伝演算のみを採用し, ジグ部と機械部には単純遺 伝演算を行いながら PC (Pentium 400) を用いて数值実験を行った. 実験条件としては, 実際の工場のデータを用い, ジョフ数 10 , 工 程数 74 (1 ジョブ当たり 3 5 工程), 工具数 20, 機械数 10 で行 った。遺伝演算は, ジョブ部において突然变異率 $0.005,1$ 点交 叉率 $0.05,2$ 点交叉率 0.05 , 逆位率 0.05 , ジダ・機械部におい て突然変異率 $0.005,1$ 点交叉率 0.05 とし, 全体では淘汰圧 0.9 , エリート保存上位 1 個体とした. このときの収束状況を図 3 に示 す. 本実験から遺伝演算では逆位が最も効果的であることが判明 した．また，これらを同時に組合せたときが最も探索効率が良い ことも分かった.

$$
4.3 \text { ディスパッチンダルールとの比較 }
$$

提案した遺伝アルゴリズムとディスパッチングルールとの比 較を上記と同じ実験で行い, その結果の日程計画の比較を行った. 比較を行ったデイパッチングルールには以下を採用した。

(1) SPT 加工時間最小の工程を選択し, アクティブスケジュー ルを作成する.ジダと機械は加工時間が最小のものを巽択する. (2) LPT 加工時間最大の工程を選択し，アクティブスケジュール を作成する. ジグと機械は加工時間が最小のものを選択する.

(3) DDATE 納期時間が最も早いものを選択し，アクティブスケ ジュールを作成する. ジグと機械は加工時間が最小のものを選択 する.

遺伝アルゴリズムの設定条件は前節と同じとし, ウェイトはすべ て 1.0 と置き, 10 例の問題を乱数で作成して数值計算を実施した. また, 全遺伝演算を採用した. Pentium $(400 \mathrm{MHz})$ を用いて計算し たとき得られた結果の平均値を表 1 に示す. 表 1 において Time は計算時間を示す。これから，提案手法が優れた方法である

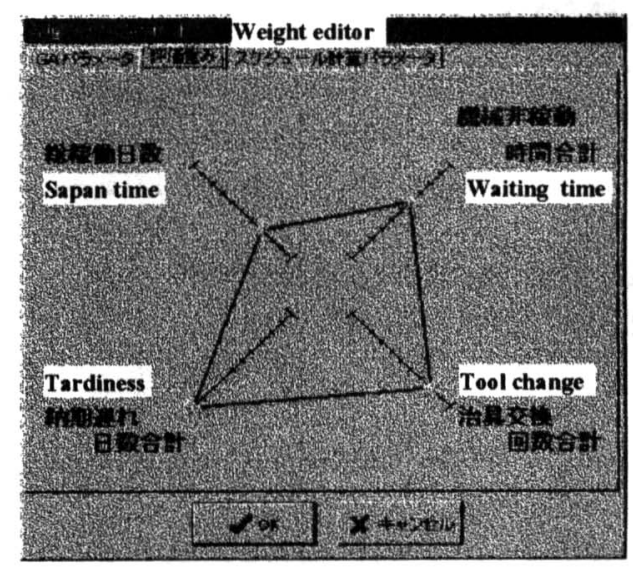

Fig. 3 Weight input by use of a radar chart

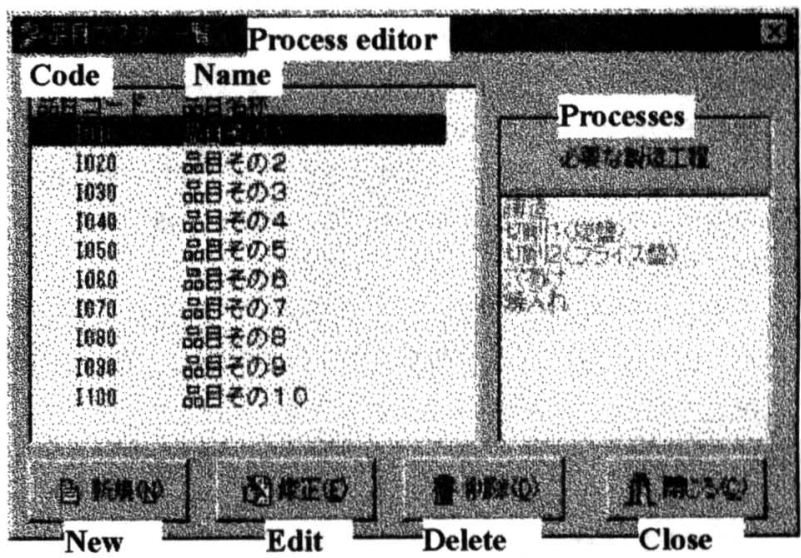

Fig.4 A product database

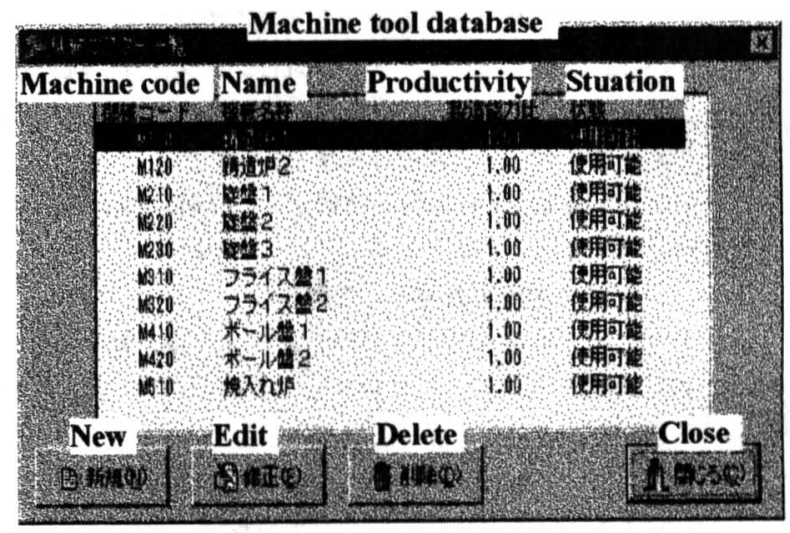

Fig. 5 A machine tool database

ことが分かる。

5. ユーザインターフェースの作成

本研究で開発した遺伝アルゴリズムを工場の現場で簡便に使 用可能とするため, ビジュアルC++を用いてダラフィックスイン ターフェース（GUI）を作成した，その概要は以下のとおりであ 3.

\section{1 遺伝アルゴリズムのパラメータ設定}

遺伝演算の実行比, ウェイトの設定を GUI 化した. 各演算のパ ラメータ值はボックスメニューからタイプし, ウェイトはレータ チャート上で工場の状況に合わせてマウスで設定する。レータチ ヤートを図 3 に示す. 


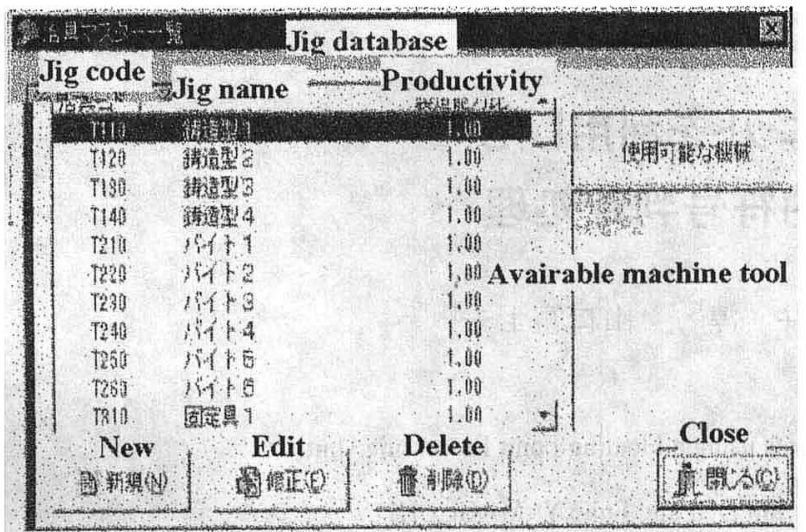

Fig. 6 A jig database

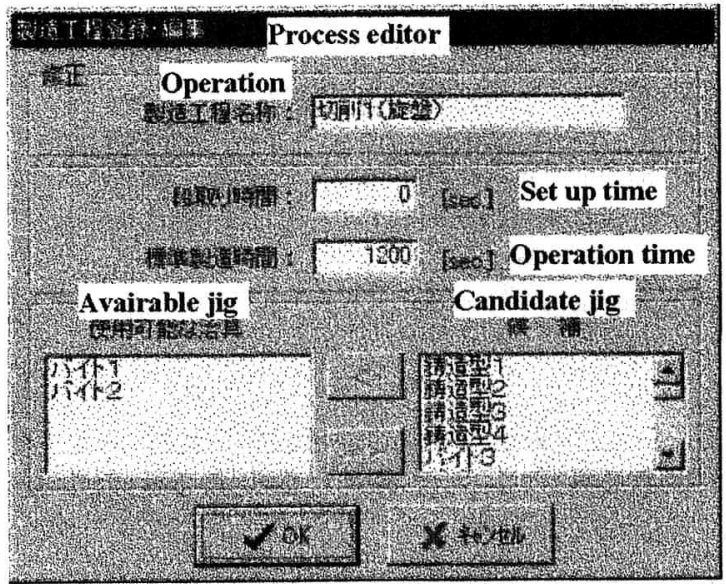

Fig. 7 A process editor

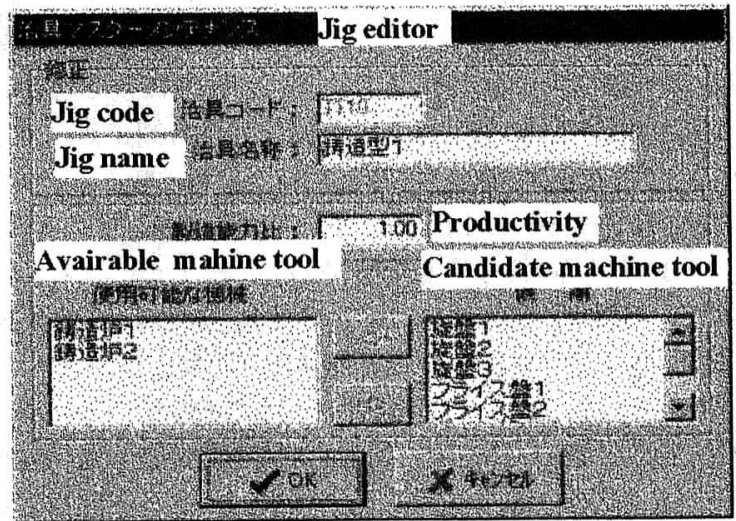

Fig. $8 \mathrm{~A}$ j̈g editor

5.2 ジョブ, 工程, ジグ, 機械エティタ, 出力の作成 ジョブ, 工程, ジグ, 機械エティ夕を作成し、これらのデータ ベースが自動的に容易に作成可能とした. ジョブ, 治具, 機械の データベース及びこれらのエディタを図 4〜8に示す. エディタ は新規・変更・維持に共通に利用可能である. また, データベー スは工場内に存在する既存のデータペースからも採用可能とし た. 図 9 にガントチャートによる計算結果出力の一部を示す.

\section{6. 結言}

遺伝アルゴリズムを採用した赛用的なジョブショップスケジュ

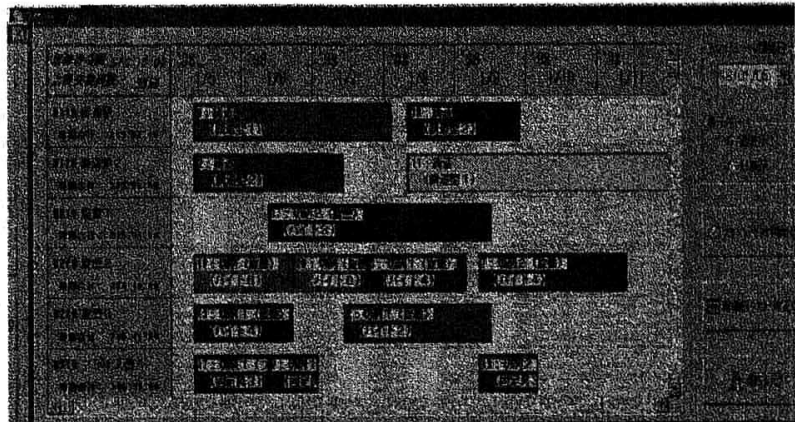

Fig. 9 An example of output by a process chart

一ラの開発を目的とし，遺伝アルゴリズムの設計，簡易なグラフ ックスインターフェースの作成を行った。これらから以下のこと が述ベられる。

（1）工程の制約条件を表現するためにジョブ部の順序表現に導 入した多重遺伝子は，小林らのアルゴリズムと比較し て，アルゴリズムが単純であるにもかかわらず十分な効果 をもち，演算時間が少なく実用的である。

(2) 割り当て問題に導入したしたジグ・機械部のモードによる 遺伝子表現は，工程によってモード数が決定するためジョ ブ部の変更によってジグ・機械部の遺伝子を操作すること なく変更された工程へのジク・機械割り当てを行える利点 在当つ。

（3）ジョブ部の多重遺伝子を採用した順序表現には，逆位演算 が大きな役割を果たすことが示された。これは順序問題に おけるサブツァー交換がよい効果を持つことに匹敵する。

（4）ディスパッチング・ルールと比較して良好な解が得られる.

(5) 実用的なスケジューラとするために，簡便なグラフィック ス・ユーザ・インターフェースを作成し，必要なデータベ 一スの作成・更新を容易にした.

本研究では，1工程に 1 工具を割り当て，その後にジダ・機械 の割り当てを行う問題を取り扱ったが，モード計算による遗伝子 表現に工具部を付加すれば容易に工具・ジグ ·機械の割り当てを 考虑したスケジューラへと拡張可能である.

\section{考 文 献}

1) 藤井進, 森田浩ほか：FMSにおけるジョプと工具の機械割り 当て法に関する研究，日本機械学会論文集 (C 編)，64，623 (1998) 2369.

2) G. Syswe rda: Schedu le Optimizat ion Us ing Ge netic Algor ithms , Handbook of Genetic A lgo rithms, Ed. by L. Davis, Van Nostran d Reinhold, (1991) 332.

3) D. Whitley, T. Starkwe at her and D. Shaner: Handbook of Genetic A lgorithms, Ed. by L. Davis), Van Nostrand Reinhold, (1991) 332.

4) 小林重信, 山村雅幸, 小野 功: GA によるジョブショップスタ ジューリンダ問題の解法, 第 3 回インテリジェントシステムシンポ ジウム諈演論文集，（1933） 227.

5) H. Tamaki, T. Mukai, K. Kawakami and M. Araki: Genetic Algorithm Approach to Multi-objective Sche du ling Problem in Plas tic Forming Plant, Ad vances in Production Management Sys te $\mathrm{ms}$ (Ed. by N. Okino, H. Tamur a and S. F ujii), Chapman \& Hall, UK, (1998) 435.

6) 大倉和博, 郷東末和, 上田完次：中立遺伝子によるジョプショ ップ・スケジューリングの解法, 日本機械学会論文集（C 編）, 63,614 (1977) 3554 .

7) 飯間 等，三宮信夫：遺伝アルゴリズムを用いた変形フローショ ップ型加工工程のスケジューリング, 第 3 回インテリジェントシス テムシンポジウム講演論文集，（1993） 215.

8) J. J. Grefenstette, R. Gopal, B. Rosmaita and D. V. Gucht: Ge netic Algor ithm for the TSP, Proc. of the First Inter national Conf. of Ge netic Algorithms, Lawre nce Erlbaum Associate, Hillsdale, (1985) 160. 